NEWS

\title{
English university funding unveiled
}

\section{Research rewarded as institutions count their share of $£ 8$ billion in government support.}

Research leaders are poring over the details of the most important financial announcement for English universities in seven years.

They will be totting up how much they - and their rivals - have won from a total of almost $£ 8$ billion (US\$11.3 billion) in government funding for research and teaching for the 2009-10 academic year, announced on 5 March. "This funding is absolutely crucial," says Alastair Smith, an economist and former vice-chancellor at the University of Sussex, Brighton. "It represents roughly half of a university's annual funding." The other half comes mainly from the seven UK research councils, which have a combined annual budget of around $£ 2.8$ billion. Universities also get research funding from charities, foundations and industry.

The funding announcement also suggests how universities' research budgets will fare for years to come. The funding has been allocated based partly on the results of the 2008 Research Assessment Exercise (RAE), the United Kingdom's most extensive audit of research quality, which was published on 18 December 2008 (see Nature 457, 13; 2009).

The 2008 RAE results will guide how the Higher Education Funding Council for England (HEFCE) allocates university cash until 2014. The funding for universities for the academic years from 2002-03 to 2008-09 was based on the previous RAE, in 2001.

The total HEFCE settlement of $£ 7.99$ billion represents a $4 \%$ increase on the previous academic year. About a fifth of that total $£ 1$.6 billion - has been awarded for research across all subject areas, representing an increase of $7.7 \%$ compared with last year (see 'Sharing the wealth'). Although university funding from HEFCE is broken down into separate allocations for teaching, research or other activities, "there are no rules on how they spend the money", says David Sweeney, director of research, innovation and skills at HEFCE.

"The view from Europe is that the RAE has overall been good for the United Kingdom," says Enric Banda, president of the

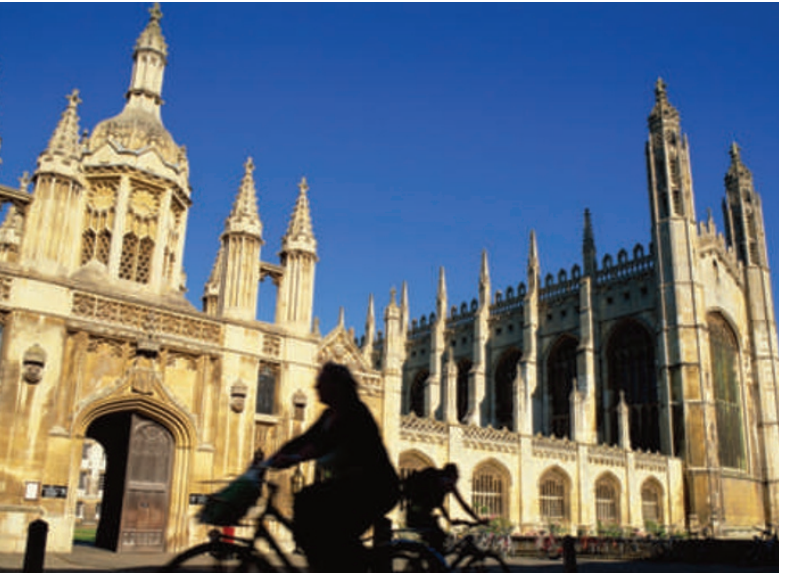

Fen funding: the University of Cambridge has won a budget boost.

some $4^{\star}$ (world-leading) research.

As HEFCE funding is divided up in part according to that quality assessment, some English universities worried that they would see significant reductions in their budgets as funding was spread more thinly.

But the 1994 Group, which represents 18 research-intensive universities, told Nature that it had been reassured by comments last week from John Denham, the secretary of state for innovation, universities and skills. In a speech on 24 February, he emphasized that the government wanted to maintain its policy of concentrating funds on the best universities.

Although universities were not able

Euroscience science-policy association, which represents universities and research institutes. "The general feeling is that Europe would benefit from a system like the RAE where part of university funding is attached to results and the best researchers are rewarded. This contrasts with universities in central and southern Europe that are not so differentiated."

HEFCE also announced that it is to make permanent an allocation of $£ 25$ million per year for teaching in expensive laboratory-based subjects, such as chemistry. First announced in 2007, the allocation was due to expire this year.

Prior to the funding announcements, some academic institutions and research leaders had expressed concern that the budget for research would be spread too thinly across the United Kingdom's 159 universities. More universities than expected were given top marks in the latest RAE, with 49 having at least

\section{SHARING THE WEALTH}

How HEFCE will allocate nearly $£ 8$ billion to universities in England in 2009-10

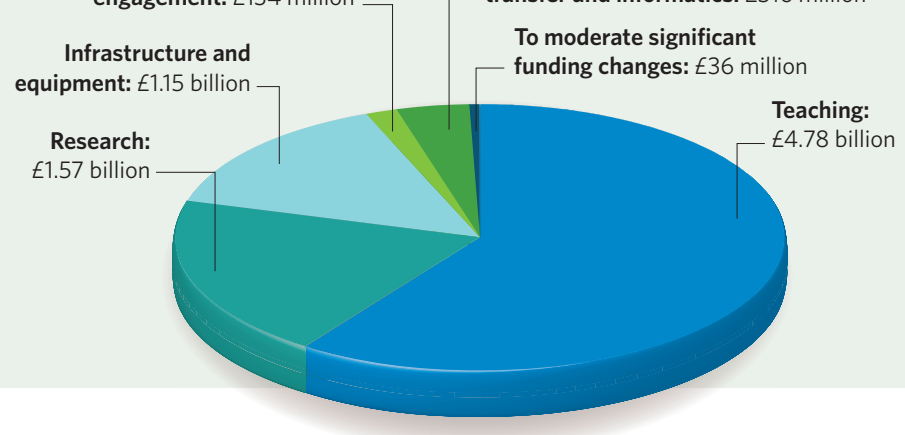

Business and community engagement: $€ 134$ million

One-off projects, including knowledge transfer and informatics: $€ 316$ million

To moderate significant funding changes: $£ 36$ million pment: $€ 1.15$ billio to comment on the results of the funding breakdown as Nature went to press, the allocations are clearly good news for those institutions.

In the latest RAE, the University of Cambridge had the greatest number of staff judged as doing 'world-leading' or 'internationally excellent' research in both biological sciences and physics. That performance has helped to secure almost $£ 181.4$ million in HEFCE funding for 2009-10, a $2.1 \%$ rise on the previous academic year.

The University of Oxford, which narrowly led the field in the chemistry assessment, has been awarded nearly $£ 187.5$ million, a 4.7\% hike on last year. Only two other universities were awarded more than $£ 180$ million: the University of Manchester, which was allocated $£ 188.9$ million, and the teachingfocused Open University in Milton Keynes, which received $£ 196.2$ million.

The University of Edinburgh, which led in the Earth sciences category, will have to wait until 2 April to find out how much it will get, when the Scottish Funding Council announces how it will fund institutions. Welsh universities will hear from their funding council on 16 March, and those in Northern Ireland will find out at the end of the month.

HEFCE will begin disbursing its funding to English universities on 1 August. Natasha Gilbert at www.hefce.ac.uk.

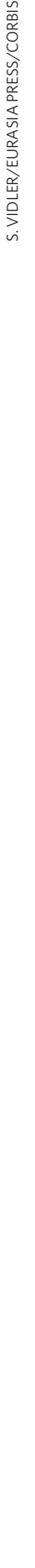

